The Journal of Animal \& Plant Sciences, 31(2): 2021, Page: 394-402

ISSN (print): 1018-7081; ISSN (online): 2309-8694

\title{
EFFECTS OF DIETARY THYME ON IMMUNE CELLS, THE ANTIOXIDANT DEFENCE SYSTEM, CYTOKINE CASCADE, PRODUCTIVE PERFORMANCE AND EGG QUALITY IN LAYING HENS
}

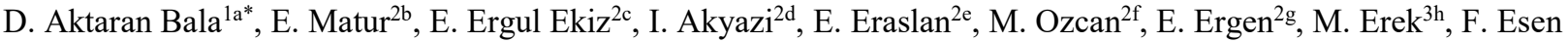 \\ Gursel $^{4 \mathrm{i}}, \mathrm{H}$. Eseceli ${ }^{5 \mathrm{j}}$ and M. Keten ${ }^{3 \mathrm{k}}$
}

\begin{abstract}
${ }^{1}$ Istanbul University-Cerrahpasa, Vocational School of Veterinary Medicine, Food Processing Department, Food Technology Programme, TR-34320 Avcilar, İstanbul- TURKEY

${ }^{2}$ Istanbul University-Cerrahpasa, Faculty of Veterinary Medicine, Department of Physiology, TR-34320 Avcilar, İstanbulTURKEY; ${ }^{3}$ Istanbul University-Cerrahpasa, Graduate Education Institute, TR-34320 Avcilar,İstanbul-TURKEY
\end{abstract}

${ }^{4}$ Istanbul University-Cerrahpasa, Faculty of Veterinary Medicine, Department of Biochemistry, TR 34320 Avcilar, İstanbul-TURKEY ; ${ }^{5}$ Bandirma Onyedi Eylul University, Faculty of Health Sciences, Department of Nutrition and Dietetics, Department of Nutrition Sciences,TR-10200 Bandirma, Balikesir- TURKEY

*Correspondence Author's e-mail: deniz.bala@istanbul.edu.tr

aOORCID:0000-0003-1512-8552; ' ORCID:0000-0003-0737-8148; 'ORCID:0000-0003-2931-3257; 'ORCID: 0000-00028808-8216; ' $O R C I D: \quad 0000-0002-5314-5970$; ${ }^{f}$ ORCID: 0000-0003-1135-4448; ' $\mathrm{g} O R C I D: \quad 0000-0001-8655-7384$;


5274-8032

\begin{abstract}
The study aims to investigate the effects of dietary supplementation of thyme on the antioxidant defence mechanisms, immune system, inflammatory cytokines, and production performance and egg quality traits in laying hens. A total of 120, 24-week-old Lohmann-Brown-Classic laying hens were used in this study. The experimental groups were fed on a ration containing $0.1 \%, 0.5 \%$, and $1 \%$ thyme, respectively for 30 days while the control group received the standard chicken feed. Certain parameters such as feed conversion rate $(\mathrm{g} / \mathrm{g})$, egg production rate $(\%)$, egg mass $(\mathrm{g} / \mathrm{hen} / \mathrm{day})$ and egg quality were evaluated. Furthermore, differential leukocyte count, heterophil/lymphocyte ratio and certain cytokine levels were assessed. Serum malondialdehyde (MDA), catalase (CAT), superoxide dismutase (SOD), ascorbic acid and glutathione peroxidase (GSH-Px) levels were measured to assess the effects of thyme on the antioxidant defence system. Serum interleukin-4 (IL-4) and GSH-Px activity levels decreased in the $0.1 \%$ and $0.5 \%$ thyme groups, respectively compared to those of the control group $(\mathrm{p} \leq 0.05)$. The leukocyte differential counts, as well as heterophil/lymphocyte ratio, did not differ significantly except for a gradual increase in leukocytes and a significant decrease in basophils with the increasing thyme concentration. Likewise, thyme supplementation did not affect performance parameters but exhibited a significant impact on egg yolk color intensity while shell weight, shell thickness, and breaking strength were negatively affected ( $\mathrm{p} \leq$ 0.05). It can be deduced that the thyme-supplemented diet did not elicit positive effects on either the antioxidant defence system or the downregulation of inflammation. That the hens experienced no difficulty in consuming the thymesupplemented diet in the study is considered promising for further studies to be carried out, concerning the effects of higher concentrations of thyme.
\end{abstract}

Keywords: cytokines, immune system, laying hens, leukocyte, thyme powder.

https://doi.org/10.36899/JAPS.2021.2.0227

Published online October 03,2020

\section{INTRODUCTION}

Antibiotics are widely used in the poultry industry and animal husbandry for prophylaxis and to promote growth and yield (Diaz-Sanchez et al., 2015). However, the use of antibiotics has been restricted in several countries, particularly in the European Union, due to antibiotic resistance and residues (Castanon 2007), in which an apparent twist of consumers toward healthier foods also played a major role. Therefore, researchers have inclined to the development of novel natural feed additives that may replace antibiotics (Zhang and An 2007, Ghasemi et al., 2010, Kaya et al., 2013). Moreover, research has focused more on strengthening the immune system (Stringfellow et al., 2011) or improving the welfare of animals (Moe et al., 2010) to reduce the necessity for antibiotics. Since antibiotic use is more prevalent in the poultry industry, an increasing number of alternative studies have been conducted in this field (Ghasemi et al., 2010).

Thyme is an ancient herbaceous plant belonging to the family Lamiaceae. It has more than 400 species and is prevalent worldwide despite its Mediterranean origin (Farsani et al., 2016). The most prevalent species is 
Thymus vulgaris L. known as German thyme or garden thyme. It has long been used for medical purposes and recent studies have pointed at the antimicrobial features of thyme which are associated with thymol and carvacrol (Helander et al., 1998) in its content. Furthermore, thyme or thyme-based compounds were shown to exhibit antifungal, anti-inflammatory, and antioxidant properties (Jones 2001).

Although healing properties of thyme have been placed forefront, studies are pointing to the ineffectiveness of the plant (Kovacs et al., 2016) and even its adverse effects on the immune system (Amirghofran 2012, Gholijani and Amirghofran 2016). So far, only a few studies have investigated the effects of thyme on poultry. The antibody production and the weight of bursa of Fabricius increased in broiler chicks which received thyme oil, in direct proportion to the concentration applied (Alipour et al., 2015). Therefore, we believe that further comprehensive research is needed to elucidate the potential effects of thyme on the immune system.

Cytokines are proteins or peptides produced by macrophages, lymphocytes, mast cells, endothelial cells, fibroblasts, and stromal cells (Zhang and An 2007). They play a significant role in the activity of defence cells and the regulation of immune reactions (Wigley and Kaiser 2003). Constituents of thyme such as thymol and carvacrol inhibited the specific immune response by reducing the expression of cytokines such as interleukin-2 (IL-2), interferon-gamma (IFN- $\gamma$ ), interleukin-4 (IL-4), interleukin-17A, and transforming growth factor-beta (TGF- $\beta$ ) in rats (Gholijani and Amirghofran 2016). To the best of our knowledge, the link between thyme and the pro-inflammatory and anti-inflammatory cytokines has not been investigated in laying hens.

Reactive oxygen compounds exerted during metabolic activities lead to oxidative stress and immune defence reactions are the most significant source of reactive compounds in the organism (Marri and Richner 2015). For instance, phagocytic cells release reactive compounds such as hydrogen peroxide to kill bacteria (Swindle and Metcalfe 2007). Therefore, the present study reveals that the defence mechanisms should be evaluated along with antioxidant reactions in the chickens that receive thyme. In this context, the present study investigates the effects of a thyme-supplemented diet on the antioxidant defence mechanisms, the immune system, pro-inflammatory/anti-inflammatory cytokines, egg production performance, and egg quality traits in laying hens.

\section{MATERIALS AND METHODS}

Ethical approval was obtained from the Animal Care and Ethics Committee of the Institute of Health Sciences of Istanbul University (28/11/2016-35980450050.01.04).
Experimental design: A total of 120, 24-week-old Lohmann Brown-Classic laying hens obtained from a commercial company were used in the study. The hens were provided 4 weeks to adapt the new conditions before the experiment. Afterward, they were randomly divided into 4 groups, each consisting of 30 hens. Each group was replicated 5 times with 6 birds per cage (Abdel-Wareth et al., 2013). All birds were fed commercial laying hens feed. Dried thyme powder was purchased from a commercial company and was added to the diet of the experimental groups at the concentrations of $0.1 \%, 0.5 \%$, and $1 \%$, respectively (Bolukbasi and Erhan, 2007) (Table 1). Thyme powder was not added to the ration of the control group. All birds were fed for 30 days. The amount of feed to be consumed by a hen per day was adjusted under the instructions of the Lohmann firm (Cuxhaven/Germany) and the drinking water was given ad libitum.

Composition of the ration: The composition of the laying hen feed used for the control and the experimental groups were given in Table 1. The ration was formulated isocalorically and isonitrogenously based on dry matter to incorporate $16 \%$ raw protein and $10.65 \mathrm{MJ} / \mathrm{kg}$ (2544 $\mathrm{Kcal} / \mathrm{kg}$ ) of metabolizable energy by an Animal Feed Optimization Software program. Common ingredients of all rations were corn, sunflower seed meal (SFSM), wheat and soybean meal (SBM).

Thyme powder was provided by a commercial enterprise (MBD Feed Industry and Trade Ltd. Co.).

Determination of the amounts of nutrients and energy content of the rations: Chemical analysis of the experimental rations was performed in accordance with the methods established by the Association of Official Analytic Chemists (AOAC 1984) and the results were presented in Table 2. The amount of nitrogen-free core matter and metabolizable energy levels were calculated based on the results of the chemical analysis. Metabolizable energy levels of the chicken feeds (ME, $\mathrm{MJ} / \mathrm{kg}$ feed) were assessed based on crude fat, crude protein, starch, and sugar contents in the feed (Kirchgessner 1997).

ME, $\mathbf{M J} / \mathbf{k g}$ feed $=(0.03431 \mathrm{x}$ crude fat, $\mathrm{g} / \mathrm{kg})+(0.01551$ $\mathrm{x}$ crude protein, $\mathrm{g} / \mathrm{kg})+(0.01669 \times \mathrm{x}$ starch, $\mathrm{g} / \mathrm{kg})+$ (0.01301 x sugar, $\mathrm{g} / \mathrm{kg}$ )

Cages and housing conditions: All hens were housed in commercial stainless-steel batteries, consisting of wire mesh cages (width $=240 \mathrm{~cm}$, length $=63 \mathrm{~cm}$, height $=50$ $\mathrm{cm}$ ) which were equipped with a feeder and nipple drinkers. A total of $2520 \mathrm{~cm}^{2}$ space was provided per chicken, including the nest area and the perch. The housing conditions (e.g. light, temperature, and ventilation) were maintained according to the Laying Hens (LohmannBrown-Classic) Breeding Standards of Lohmann Company. 


\section{Parameters evaluated}

Production performance: Feed conversion rate, egg production rate and average egg mass were estimated by monitoring the daily feed consumption, the number of eggs produced per day, and egg weight as follows:

Feed Conversion Rate (FCR) (g/g): Consumed food (gram)/produced egg (gram)

Egg Production Rate (EPR) (\%): (Daily egg production/number of hens) $\times 100$

Egg Mass (EM) (g/hen/day): (Egg Production Rate/100) x average egg weight (gram)

Measurement of egg quality: Two eggs from each subgroup (a total of 10 eggs from each group) were collected weekly and egg weight (Wt), eggshell strength, albumen height (Ht), Haugh unit (HU), yolk color (ycf), eggshell thickness, and eggshell weight were measured by a digital tester (Digital Egg Tester DET 6000, Nabel, JAPAN). Yolk color intensity was evaluated on a scale between 1 to 16 available on the device (DET 6000, Nabel, JAPAN).

Collection of blood samples and separation of sera: At the end of the experimental procedure, blood samples were collected both in heparinized and anticoagulant-free tubes from randomly selected 2 hens belonging to each replicated group (a total of 10 blood samples from each experimental group). Blood in heparinized tubes was used to determine the differential leukocyte count. Percentages of heterophils, lymphocytes, monocytes, eosinophils, and basophils were evaluated on blood smears under light microscopy. Anticoagulant-free blood tubes were centrifuged at $3000 \mathrm{rpm}$ for $15 \mathrm{~min}$; serum samples were separated and then stored at $-80{ }^{\circ} \mathrm{C}$ until the analysis.

Analysis of cytokine levels: Serum IL-1 $\beta$, IL-2, IL-6, IL8 , tumor necrosis factor- $\alpha$ (TNF- $\alpha$ ), IFN- $\gamma$ and IL-4, IL10 , IL-13, TGF- $\beta$ levels were measured to determine the pro-inflammatory and anti-inflammatory response, respectively. Analysis of cytokine levels was performed by ELISA using a commercially available kit (Rayto RT $\left.600^{\circ}\right)$. The analyses were carried out under the instructions established for chicken-specific kits (Fayez et al. 2018).

Assessment of parameters concerning the antioxidant defence system: Serum malondialdehyde (MDA) (Yoshoiko et al., 1979), catalase (CAT) (Yasmineh et al., 1995), superoxide dismutase (SOD)( Sun et al., 1988) and ascorbic acid (Haag 1985) levels were assessed by spectrophotometry whereas the glutathione peroxidase (GSH-Px) level was estimated by ELISA using commercially available kits (Rayto RT600 ${ }^{\circ}$ ).

Statistical Analyses: Data collected from all groups were analyzed via Shapiro-Wilk tests to check for normal distribution. Normally distributed parameters were compared by one-way ANOVA and non-normal distributions were subjected to Kruskal Wallis nonparametric tests. Bonferroni correction was applied for non-normally distributed parameters and overall data of the groups were compared via Mann Whitney U tests. The statistical significance level was established as $\mathrm{P}=0.05$. SPSS software program (SPSS for Windows, version 11.5.2.1) was used for the statistical analyses.

The test statistic for testing the null hypothesis that all means are equal via one-way ANOVA is given as:

$$
\mathrm{F}=\frac{\sum \mathrm{n}_{\mathrm{j}}\left(\overline{\mathrm{X}}_{\mathrm{j}}-\overline{\mathrm{X}}\right)^{2} /(\mathrm{k}-1)}{\sum \sum\left(\mathrm{X}-\overline{\mathrm{X}}_{\mathrm{J}}\right)^{2} /(\mathrm{N}-\mathrm{k})}
$$

$\mathrm{n}_{\mathrm{j}}$ : sample size in the $\mathrm{jth}$ group

$\overline{\mathrm{X}}_{\mathrm{J}}$ : sample mean in the $\mathrm{jth}$ group

$\overline{\mathrm{X}}$ : overall mean

$\mathrm{k}$ : number of independent groups

$\mathrm{N}$ : total number of observations in the analysis

And the test statistic for testing the null hypothesis that samples originate from the same distribution via Kruskal Wallis is given as follows:

$$
H=(N-1) \frac{\sum_{i=1}^{g} n_{i}\left(\bar{r}_{i}-\bar{r}\right)^{2}}{\sum_{i=1}^{g} \sum_{j=1}^{n_{i}}\left(r_{i j}-\bar{r}\right)^{2}}
$$

$\mathrm{n}_{\mathrm{i}}$ : number of observations in group $\mathrm{i}$

$r_{i j}$ : the rank of observation $j$ from group $i$

$\mathrm{N}$ : total number of observations across all groups

\section{RESULTS}

Data indicating the production performance were presented in Table 5. It was found that thyme supplementation did not significantly affect the FCR, EPR, and $E M$ values $(\mathrm{p}>0.05)$.

Parameters for egg quality were recapitulated in Table 6. Eggshell strength decreased significantly in the group that was given $0.5 \%$ of thyme in comparison to that in the control group $(\mathrm{p} \leq 0.05)$. Yolk color scores were higher in all groups that received thyme when compared to those of the control group $(\mathrm{p} \leq 0.05)$. Furthermore, higher concentrations of thyme $(0.5 \%$ and $1 \%)$ increased yolk color intensity in comparison to the $0.1 \%$ thyme group ( $\mathrm{p}$ $\leq 0.05$ ). Eggshell weights were significantly lower in the laying hens that were administered $0.5 \%$ of thyme in comparison to both the control and 1\% thyme groups ( $\mathrm{p} \leq$ $0.05)$. Eggshell thickness was found to have reduced in the same group $(0.5 \%$ thyme) when compared to that of the group that received $0.1 \%$ thyme $(p \leq 0.05)$ but, no significant differences were noted among other groups in terms of eggshell thickness. Likewise, no statistically significant differences were detected among groups in terms of other parameters of egg quality (Table 6).

Data regarding differential leukocyte count were shown in Table 7. Thyme exhibited no impact on heterophil, and eosinophil percentages. On the other hand $\mathrm{H} / \mathrm{L}$ ratio was found to be decreased in chickens who added $0.5 \%$ and $1 \%$ thyme to their feed $(\mathrm{P}=0.018)$. On 
the contrary, the basophil ratio was detected to be higher in the group of lowest thyme concentration and significantly reduced in parallel with the increasing concentration of the supplementation (Table 7).

No significant difference was noted between groups in terms of the levels of pro-inflammatory cytokines such as IL-1 $\beta$, IL-2, IL-6, IL-8, TNF- $\alpha$, and INF$\gamma(p>0.05)$. Likewise, no statistically significant difference was obtained for IL-10, IL-13, and TGF- $\beta$ levels ( $p>0.05)$; however, IL-4 level decreased significantly in the group that received $0.1 \%$ of thyme compared to the control group $(\mathrm{p} \leq 0.05)$ (Table 3$)$.

Serum MDA, SOD, CAT, and ascorbic acid levels were shown in Table 4. These parameters did not differ significantly $(p>0.05)$. On the other hand, the level of GSH-Px activity was found to have decreased in the group that was given $0.5 \%$ of thyme compared to the control group $(\mathrm{p} \leq 0.05)$.
Table 1. Composition of the ration given to the hens.

\begin{tabular}{lc}
\hline Ingredient & $\%$ \\
Corn & 28 \\
Sunflower seed meal & 15 \\
Soybean meal & 13 \\
Wheat & 38 \\
Marble powder & 19 \\
l-Lysine & 0.12 \\
DL-Methionine & 0.13 \\
Salt & 0.2 \\
Vitamin-mineral premix* & 0.3 \\
Vegetable oil & 0.2 \\
Antioxidant & 0.06 \\
\hline Vitamin and trace mineral complexes provided the following (per \\
kg of diet): vitamin A (retinyl palmitate), 15,000 IU; vitamin D3, \\
2,500 IU; vitamin E (DL- $\alpha$-tocopheryl acetate), 20 mg; vitamin \\
B1, 3 mg; vitamin B2, 7,5 mg; D-pantothenic acid, 25 mg; \\
vitamin B6, 5 mg; vitamin B12, 0.002 mg; biotin, 0.5 mg; niacin, \\
25 mg; vitamin K3, 1.25 mg; folic acid, 1.5 mg; choline chloride, \\
750 mg; cobalt, 1.2 mg; copper, 8.8 mg; zinc, 84 mg; manganese, \\
106 mg; iron, 44 mg; iodine, 1.2 mg; and selenium, 0.15 mg..
\end{tabular}

Table 2. Nutrient content (\%) and energy levels (ME, MJ/kg feed) of the rations.

\begin{tabular}{lcccc}
\hline \multirow{2}{*}{ Nutritional Component } & \multicolumn{3}{c}{ Experimental Groups } \\
\cline { 2 - 5 } & Control & $\mathbf{0 . 1} \%$ thyme & $\mathbf{0 . 5} \%$ thyme & $\mathbf{1} \%$ thyme \\
\hline Moisture, \% & 12.6 & 11.92 & 12.4 & 11.97 \\
Dry matter, \% & 87.4 & 88.08 & 87.6 & 88.03 \\
Crude protein, \% & 16.18 & 16.55 & 16.06 & 16.17 \\
Crude fat, \% & 2.03 & 2.17 & 2.1 & 2.08 \\
Crude fibre, \% & 4.8 & 4.83 & 5.13 & 4.99 \\
Ash, \% & 7.7 & 8.18 & 7.75 & 7.81 \\
Nitrogen-free core matter ${ }^{*} \%$ & 56.69 & 56.35 & 56.56 & 56.98 \\
Starch & 42.17 & 41.09 & 41.52 & 42.5 \\
Sugar & 3.4 & 3.41 & 3.45 & 3.43 \\
Calcium, \% & 1.79 & 1.9 & 1.79 & 1.79 \\
Utilizable phosphorus, \% & 0.44 & 0.44 & 0.43 & 0.43 \\
ME, MJ/kg feed & 10.69 & 10.61 & 10.6 & 10.76 \\
\hline
\end{tabular}

${ }^{*}$ Nitrogen-free core matter ${ }^{*}, \%=$ Dry matter, $\%$ - (crude protein, $\%+$ crude fat, $\%+$ crude fiber, $\%+$ ash, $\%$ )

${ }^{* *} \mathrm{ME}, \mathrm{MJ} / \mathrm{kg}$ yem $=(0,03431 \mathrm{x}$ crude fat, $\mathrm{g} / \mathrm{kg})+(0,01551 \mathrm{x}$ crude protein, $\mathrm{g} / \mathrm{kg})+(0,01669 \mathrm{x} \mathrm{starch}, \mathrm{g} / \mathrm{kg})+(0,01301 \mathrm{x} \mathrm{sugar}, \mathrm{g} / \mathrm{kg})$ 
Table 3. Cytokine cascade in laying hens after administration of dietary thyme.

\begin{tabular}{|c|c|c|c|c|c|c|c|c|c|}
\hline & \multicolumn{2}{|c|}{ Control } & \multicolumn{2}{|c|}{ Thyme (0.1\%) } & \multicolumn{2}{|c|}{ Thyme (0.5\%) } & \multicolumn{2}{|c|}{ Thyme (1\%) } & \multirow[b]{2}{*}{$P$ values } \\
\hline & Mean & SE & Mean & SE & Mean & SE & Mean & SE & \\
\hline IL-13 (pg/ml) & 67.80 & 0.84 & 68.39 & 1.70 & 66.44 & 0.90 & 67.32 & 1.40 & 0.881 \\
\hline IL-1及 (pg/ml) & 8.41 & 0.19 & 8.25 & 0.10 & 8.45 & 0.08 & 8.47 & 0.11 & 0.262 \\
\hline IL-8 (pg/ml) & 7.78 & 0.03 & 7.70 & 0.04 & 7.77 & 0.02 & 7.76 & 0.06 & 0.547 \\
\hline IL-10 (pg/ml) & 4.28 & 0.07 & 4.38 & 0.09 & 4.34 & 0.07 & 4.50 & 0.17 & 0.822 \\
\hline IL-6 (pg/ml) & 7.39 & 0.05 & 7.37 & 0.05 & 7.46 & 0.09 & 7.32 & 0.04 & 0.826 \\
\hline IL-4 (pg/ml) & $6.65^{\mathrm{a}}$ & 0.05 & $6.42^{\mathrm{b}}$ & 0.05 & $6.55^{\mathrm{ab}}$ & 0.11 & $6.58^{\mathrm{ab}}$ & 0.06 & 0.042 \\
\hline TNF- $\boldsymbol{\alpha}(\mathrm{pg} / \mathrm{ml})$ & 7.76 & 0.07 & 7.77 & 0.07 & 7.78 & 0.06 & 7.71 & 0.07 & 0.764 \\
\hline IFN- $\boldsymbol{\gamma}(\mathrm{pg} / \mathrm{ml})$ & 5.91 & 0.13 & 5.81 & 0.13 & 5.89 & 0.09 & 5.65 & 0.06 & 0.237 \\
\hline TGF- $\boldsymbol{\beta}(\mathrm{pg} / \mathrm{ml})$ & 7.44 & 0.16 & 7.41 & 0.08 & 7.56 & 0.24 & 7.25 & 0.09 & 0.761 \\
\hline IL-2 (pg/ml) & 7.74 & 0.05 & 7.86 & 0.08 & 7.73 & 0.08 & 7.73 & 0.05 & 0.511 \\
\hline
\end{tabular}

Table 4. Effects of dietary thyme supplementation on antioxidant defence system parameters in laying hens

\begin{tabular}{lccccccccccc}
\hline & \multicolumn{2}{c}{$\begin{array}{c}\text { SOD } \\
(\mathrm{U} / \mathrm{mL})\end{array}$} & \multicolumn{2}{c}{$\begin{array}{c}\text { MDA } \\
(\mathrm{nmol} / \mathrm{mL})\end{array}$} & \multicolumn{2}{c}{$\begin{array}{c}\text { CAT } \\
(\mathrm{U} / \mathrm{ml})\end{array}$} & \multicolumn{2}{c}{$\begin{array}{c}\text { Ascorbic Acid } \\
(\mu \mathrm{mol} / \mathrm{L})\end{array}$} & \multicolumn{2}{c}{$\begin{array}{c}\text { GSH-Px } \\
(\mathrm{pg} / \mathrm{mL})\end{array}$} \\
\hline & Mean & SE & Mean & SE & Mean & SE & Mean & SE & Mean & SE \\
Control & 23.81 & 4.97 & 15.48 & 3.79 & 42.96 & 11.27 & 10.44 & 0.25 & $7.29^{\mathrm{a}}$ & 0.07 \\
Thyme (0.1\%) & 12.50 & 5.16 & 9.66 & 2.00 & 62.33 & 16.48 & 10.73 & 0.15 & $7.13^{\mathrm{ab}}$ & 0.04 \\
Thyme (0.5\%) & 16.17 & 6.24 & 18.59 & 3.88 & 39.45 & 10.57 & 14.95 & 5.23 & $7.08^{\mathrm{b}}$ & 0.04 \\
Thyme (1\%) & 21.21 & 5.34 & 9.48 & 2.78 & 36.72 & 5.21 & 9.97 & 0.36 & $7.15^{\mathrm{ab}}$ & 0.05 \\
$P$-value & \multicolumn{2}{c}{0.224} & \multicolumn{2}{c}{0.163} & \multicolumn{2}{c}{0.741} & 0.056 & 0.032 \\
\hline
\end{tabular}

$\mathrm{a}, \mathrm{b}$ : There is a significant differences between the means indicated with different letters on the same column. SOD: Superoxide dismutase; MDA: Malondialdehyde ; CAT: Catalase; GSH-Px: Glutathione peroxidase

Table 5. Effects of dietary thyme supplementation on production parameters in laying hens

\begin{tabular}{lcccccc}
\hline & \multicolumn{2}{c}{$\begin{array}{c}\text { EPR } \\
\text { (g/hen/day) }\end{array}$} & \multicolumn{2}{c}{$\begin{array}{c}\text { EM } \\
\text { (\%) }\end{array}$} & \multicolumn{2}{c}{$\begin{array}{c}\text { FCR } \\
\text { (g/g) }\end{array}$} \\
\hline & Mean & SE & Mean & SE & Mean & SE \\
Control & 74.88 & 1.67 & 37.78 & 0.95 & 2.81 & 0.71 \\
Thyme (0.1\%) & 71.55 & 1.21 & 35.46 & 0.85 & 2.99 & 0.73 \\
Thyme (0.5\%) & 78.71 & 4.17 & 38.83 & 1.51 & 2.74 & 0.12 \\
Thyme (1\%) & 76.33 & 4.37 & 37.32 & 2.19 & 2.88 & 0.18 \\
$P$-value & \multicolumn{2}{c}{0.471} & \multicolumn{2}{c}{0.457} & & \\
\hline
\end{tabular}

a, b: There is a significant differences between the means indicated with different letters on the same column. EPR:

Egg production rate; EM: Egg mass; FCR: Feed conversion rate. 
Table 6. Effects of dietary thyme supplementation on egg quality parameters in laying hens

\begin{tabular}{|c|c|c|c|c|c|c|c|c|c|c|c|c|c|c|}
\hline & \multicolumn{2}{|c|}{$\begin{array}{c}\text { Egg weight } \\
(\mathrm{g})\end{array}$} & \multicolumn{2}{|c|}{$\begin{array}{c}\text { Shell strenght } \\
\text { (kgf) }\end{array}$} & \multicolumn{2}{|c|}{$\begin{array}{c}\text { Albumen height } \\
(\mathrm{mm})\end{array}$} & \multicolumn{2}{|c|}{ Haugh unit } & \multicolumn{2}{|c|}{ Yolk color } & \multicolumn{2}{|c|}{$\begin{array}{c}\text { Eggshell thickness } \\
(\mathrm{mm})\end{array}$} & \multicolumn{2}{|c|}{$\begin{array}{c}\text { Shell weight } \\
\text { (g) }\end{array}$} \\
\hline & Means & $\mathrm{SE}$ & Means & SE & Means & $\mathrm{SE}$ & Means & $\mathrm{SE}$ & Means & $\mathrm{SE}$ & Means & $\mathrm{SE}$ & Means & $\mathrm{SE}$ \\
\hline Control & 53.40 & 0.70 & $4.39^{\mathrm{a}}$ & 0.15 & 7.14 & 0.23 & 85.43 & 1.65 & $2.92^{\mathrm{c}}$ & 0.18 & $0.35^{\mathrm{a}}$ & 0.04 & $6.11^{\mathrm{a}}$ & 0.59 \\
\hline $\begin{array}{l}\text { Thyme } \\
(0.1 \%)\end{array}$ & 53.32 & 0.82 & $3.98^{\mathrm{ab}}$ & 0.13 & 7.42 & 0.37 & 87.89 & 1.87 & $3.72^{\mathrm{b}}$ & 0.12 & $0.35^{\mathrm{a}}$ & 0.03 & $6.03^{\mathrm{ab}}$ & 0.70 \\
\hline $\begin{array}{l}\text { Thyme } \\
(0.5 \%)\end{array}$ & 53.80 & 0.83 & $3.56^{\mathrm{b}}$ & 0.16 & 9.20 & 1.73 & 87.00 & 1.26 & $4.37^{\mathrm{a}}$ & 0.11 & $0.32^{\mathrm{b}}$ & 0.07 & $5.69^{\mathrm{b}}$ & 0.12 \\
\hline $\begin{array}{l}\text { Thyme } \\
(1 \%)\end{array}$ & 52.01 & 0.74 & $3.93^{\mathrm{ab}}$ & 0.15 & 7.47 & 0.16 & 88.12 & 1.20 & $4.32^{\mathrm{a}}$ & 0.12 & $0.35^{\mathrm{a}}$ & 0.03 & $6.13^{\mathrm{a}}$ & 0.11 \\
\hline$P$-value & \multicolumn{2}{|c|}{0.576} & \multicolumn{2}{|c|}{0.006} & \multicolumn{2}{|c|}{0.613} & 0.59 & & \multicolumn{2}{|c|}{0.001} & \multicolumn{2}{|c|}{0.002} & \multicolumn{2}{|c|}{0.01} \\
\hline
\end{tabular}

a, b, c: There is a significant differences between the means indicated with different letters on the same colum

Table 7. Effects of dietary thyme supplementation on differential leukocyte count in laying hens

\begin{tabular}{|c|c|c|c|c|c|c|c|c|c|c|c|c|}
\hline \multirow[t]{2}{*}{ Group } & \multicolumn{2}{|c|}{ H /L ratio } & \multicolumn{2}{|c|}{$\begin{array}{c}\text { Heterophil } \\
\%\end{array}$} & \multicolumn{2}{|c|}{$\begin{array}{c}\text { Eosinophil } \\
\%\end{array}$} & \multicolumn{2}{|c|}{$\begin{array}{c}\text { Basophil } \\
\%\end{array}$} & \multicolumn{2}{|c|}{$\begin{array}{c}\text { Lymphocyte } \\
\%\end{array}$} & \multicolumn{2}{|c|}{$\begin{array}{c}\text { Monocyte } \\
\%\end{array}$} \\
\hline & Mean & SE & Mean & $\mathrm{SE}$ & Mean & SE & Mean & $\mathrm{SE}$ & Mean & $\mathrm{SE}$ & Mean & $\mathrm{SE}$ \\
\hline Control & $3.94^{\mathrm{a}}$ & 0.50 & 69.40 & 2.72 & 1.95 & 0.43 & $5.55^{\mathrm{ab}}$ & 1.13 & $23.1^{\mathrm{b}}$ & 2.75 & $1.0^{\mathrm{ab}}$ & 0.25 \\
\hline Thyme (0.1\%) & $3.32^{\mathrm{a}}$ & 0.43 & 66.05 & 2.64 & 1.70 & 0.33 & $7.6^{\mathrm{a}}$ & 0.91 & $24.65^{\mathrm{ab}}$ & 2.13 & $0.5^{\mathrm{b}}$ & 0.20 \\
\hline Thyme (0.5\%) & $2.42^{\mathrm{b}}$ & 0.22 & 63.90 & 1.84 & 1.50 & 0.34 & $5.75^{\mathrm{ab}}$ & 0.77 & $29.3^{\mathrm{ab}}$ & 1.84 & $2.15^{\mathrm{ab}}$ & 0.58 \\
\hline Thyme (1\%) & $2.25^{\mathrm{b}}$ & 0.22 & 63.25 & 2.01 & 1.40 & 0.46 & $3.75^{\mathrm{b}}$ & 0.66 & $31.6^{\mathrm{a}}$ & 1.97 & $3.95^{\mathrm{a}}$ & 0.80 \\
\hline$P$-value & \multicolumn{2}{|c|}{0.018} & \multicolumn{2}{|c|}{0.127} & \multicolumn{2}{|c|}{0.089} & \multicolumn{2}{|c|}{0.013} & \multicolumn{2}{|c|}{0.011} & \multicolumn{2}{|c|}{0.002} \\
\hline
\end{tabular}

a, b: There is a significant differences between the means indicated with different letters on the same column $(\mathrm{p} \leq 0.05) \mathrm{H} / \mathrm{L}$ ratio: Heterophil to lymphocyte ratio

\section{DISCUSSION}

In the present study, it was clearly shown that thyme-supplemented diet exerted a null impact on the parameters regarding production performance, which is consistent with the previous studies highlighting the ineffectiveness of thyme on the performance parameters (Zeweil et al., 2006, Ghasemi et al., 2010, Abd El-Hack and Alagawany 2015).

However, regarding egg quality, the present study revealed an increase in yolk color score with thyme supplementation. This is compatible with previous studies indicating that thyme improved yolk color (Ghasemi et al., 2010), which is associated with xanthophylls naturally found in thyme and thyme-like plants (Mansoub 2011). The increase in yolk color intensity alters depending on the type and concentration of xanthophylls (Galobart et al., 2004). Even though yolk color intensity is not an indicator of the nutritional value of the egg, it may well constitute an appealing factor in terms of consumers' preferences, as the golden or orange color of the egg yolk is associated with a more favorable health status of the hen from the consumers' perspective (Caliscar and Uygur 2010). On the other hand, eggshell weight, thickness, and strength reduced significantly only in the laying hens that received $0.5 \%$ thyme in their ration $(\mathrm{p} \leq 0.05)$. Poor eggshell quality leads to serious economic consequences during incubation and transportation (Harikrishnan and Mohan 2018). According to the studies carried out by Abdel-Wareth et al., (2013) and Ghasemi et al., (2010), the thymesupplemented diet did not affect eggshell thickness. However, in another study, aromatic compounds found in thyme and similar phytogenic plants yielded significant differences in terms of the yolk color and shell quality of egg as well as the palatability and flavor (Bozkurt et al., 2014). Moreover, it was asserted that essential oil contents exhibited an affirmative impact on eggshell strength and weight (Harikrishnan and Mohan 2018).

While the differences in the heterophil ratios were found to be insignificant, the percentage of lymphocytes 
was higher in the hens that received $1 \%$ thyme in comparison to the control group. Similar results were shown with the thyme supplementation in a few studies (Ghasemi et al., 2010, Mansoub 2011, Hassan and Awad 2017). The heterophil-to-lymphocyte ratio is an accurate indicator of mild to moderate stress in poultry (Maxwell et $a l .$, 1993), which has long been recognized as the response of hypothalamic-pituitary-adrenal axis (Gross and Siegel 1983). In the present study, the monocyte ratio was higher in the $0.1 \%$ thyme group in comparison to the $1 \%$ thyme group while the basophil level was significantly reduced with the increasing concentration of thyme $(p \leq 0.05)$, which was compatible with the findings of the study conducted by Azarfar et al., (2012) with thyme and thyme derivatives. It is known that elevated basophil ratio is a physiological response induced against mild to moderate stress in poultry.

Only a few studies are available concerning the pro-inflammatory and anti-inflammatory effects of thyme on chickens. Hassan and Avvad (2017) pointed at the antiinflammatory properties of dietary thyme supplementation suggesting that thyme reduced the expression of proinflammatory cytokines such as IL-6, IFN- $\gamma$, and TNF- $\alpha$ in the jejunum of broiler chicks. In the present study, no change was detected in the serum levels of the cytokines except for IL-4. According to Gholijani and Amirghofran (2016), the levels of IL-4, as well as the other cytokines such as IL- 2 , IFN- $\gamma$, and IL-17A were decreased in the rats that received thyme. IL-4 is released by mast cells, eosinophils, basophils and Th2 cells (Chaudari et al., 2018; Wigley and Kaiser 2003). The decrease in the IL-4 level in the present study is considered to be associated with thymol and carvacrol contained in thyme since the mentioned bioactive compounds were previously indicated to have inhibited the activity of Th2 cells (Luckheeram et al., 2012). Furthermore, it was an intriguing finding in the present study that the basophil ratio was significantly reduced $(\mathrm{p} \leq 0.05)$ in the hens that received the highest concentration of thyme; yet, a quantitative decrease was noted also in eosinophils, which might be responsible for the decrease in the IL-4 level. However, collected data is considered insufficient for an exact interpretation of the underlying mechanism.

The serum GSH-Px level was lower in the group that received $0.5 \%$ thyme than in the control group (Table 3). Similarly, in another study, the liver GSH-Px level was decreased in the Japanese quails that were given thyme (Drozd et al., 2016). However, Abd El-Hack and Alagawany (2015) and Gumus et al., (2017) pointed to an increase in the level of the relevant cytokine. Such discrepancy was considered to have resulted from certain factors such as the shortness of the duration of oxidative stress that the animals were exposed to, and the difference in thyme concentration administered. Phenolic compounds found in the chemical structure of thyme were reported to have eliminated the free radicals released by the aid of hydroxyl groups (Hashemipour et al., 2013) and thus thyme reduced the production of antioxidant enzymes. It was considered that the decrease in the GSH-Px level in the present study might have been associated with this phenomenon.

Conclusions: Various thyme concentrations were reported to have improved the immune system and reinforced the antioxidant defence mechanisms (Abd El-Hack et al., 2016, Abd El-Hack and Alagawany 2015). On the other hand, some other studies had previously indicated the antimicrobial properties of thyme (Helander et al., 1998, Dorman and Deans 2000). In the presented study, dietary thyme supplementation revealed no significant impact on the antioxidant defence mechanisms and the immune system, which was considered to be associated with the rather inadequate concentration of thyme supplementation. On the other hand, one of the characteristics of egg quality such as egg yolk color was positively affected. The use of natural and healing plants as food additives alternative to antibiotics in the poultry industry and rising consumer demand for healthy foods in recent years has accelerated a great number of studies investigating the effects of thyme and similar phytomaterials. That the hens had smoothly consumed the thyme-supplemented diet in the presented study was a favorable outcome offering considerable potential for further studies to be carried out with higher concentrations of thyme.

Acknowledgments: This work was supported by the Research Fund of Istanbul University (Project number: BAP 23747).

Conflict of Interest: There is no conflict of interest in the present study.

\section{REFERENCES}

Abd El-Hack M.E. and M. Alagawany (2015). Performance, egg quality, blood profile, immune function, and antioxidant enzyme activities in laying hens fed diets with thyme powder. J. Anim. Feed Sci. 24:127-133.

Abd El-Hack M.E., M. Alagawany, M.R. Farag, R. Tiwari, K. Karthik, K. Dhama, J. Zorriehzahraf and M. Adel (2016). Beneficial impacts of thymol essential oil on health and production of animals, fish and poultry: a review. J. Essent. Oil Res. 28(5): 365-382.

Abdel-Wareth A.A.A., Z.S.H. Ismail and K.H. Sudekum (2013). Effects of thyme and oregano on performance and egg quality characteristics of laying hens. Worlds Poult. Sci. J, 69: 1-6.

Alipour F., A. Hassanabadi, A. Golian and H. NassiriMoghaddam (2015). Effect of plant extracts 
derived from thyme on male broiler performance. Poultry Sci. 94(11): 2630-2634.

Amirghofran Z. (2012). Herbal medicines for immunosuppression. Iran J Allergy Asthm. 11(2): 111-119.

AOAC. (1984). Official Methods of Analysis, 14th ed. Association of Official Agricultural Chemist. Washington, DC.

Azarfar S., A. Nobakht, Y. Memannavaz, A. Safamehr and H.A. Shahryar (2012). Influence of dietary supplemented Thyme ( Thymus vulgaris L .) and Pennyroyal ( Mentha Pulegium ) leaves on hematological indices of Japanese quails (Coturnix coturnix japonica ). Euro J Exp Bio. 2(3): 605-607.

Bolukbasi S.C. and M.K. Erhan (2007). Effect of dietary thyme (Thymus vulgaris) on laying hens performance and Escherichia coli (E. coli) concentration in feces. Int J of Nat Eng Sci. 1(2): 55-58.

Bozkurt M., F. Hippenstiel, A.A.A. Abdel-Wareth, S. Kehraus, K. Kucukyilmaz and K.H. Sudekum (2014). Effects of selected herbs and essential oils on performance, egg quality and some metabolic activities in laying hens - a review. Eur Poultry Sci. 78: 1-15.

Calislar S. and G. Uygur (2010). Effects of dry tomato pulp on egg yolk pigmentation and some egg yield characteristics of laying hens. J Anim Vet Adv. 9(1): 96-98.

Castanon J.I.R. (2007). History of the use of antibiotic as growth promoters in European poultry feeds. Poultry Sci, 86: 2466-2471.

Chaudhari A.A., W.H. Kim and H.S. Lillehoj (2018). Interleukin-4 (IL-4) may regulate alternative activation of macrophage-like cells in chickens: A sequential study using novel and specific neutralizing monoclonal antibodies against chicken IL-4. Vet Immunol Immunop. 205:7282.

Diaz-Sanchez S., S. Moscoso, F. Solís De Los Santos, A. Andino and I. Hanning (2015). Antibiotic use in poultry: A driving force for organic poultry production. Food Prot. Trends, 35(6), 440-447.

Dorman H.J.D. and S.G. Deans (2000). Antimicrobial agents from plants: antibacterial activity of plant volatile oils. J Appl Microbiol. 88: 308-316.

Drozd R., A. Rybarczyk, A. Wasak, M. Jakubowska, K. Rybak, M. Skólmowska (2016). Influence of flaxseed combined with thyme, rosemary, and sage leaves as fodder additives on antioxidant status in the liver of Japanese quail. Turk J Vet Anim Sci. 40: 359-364.

Farsani M.S., M. Behbahani and H.Z. Isfahani (2016). The effect of root, shoot and seed extracts of the Iranian Thymus L (family: lamiaceae) species on
HIV-1 replication and CD4 expression. Cell J. 18(2): 255-261.

Fayez A.M., S. Zakariab and D. Moustafa (2018). Alpha lipoic acid exerts antioxidant effect via Nrf2/HO1 pathway activation and suppresses hepatic stellate cells activation induced by methotrexate in rats. Biomed Pharmacother. 105: 428-433.

Galobart J., R. Sala, X. Rincon-Carruyo, E.G. ManZanilla, B. Vil and J. Gasa (2004). Egg yolk color as affected by saponified oleoresin of red pepper (Capsicum annuum) fed to laying hens. Poultry Sci. 69: 462-470.

Ghasemi R., M. Zarei and M. Torki (2010). Adding medicinal herbs including garlic (allium sativum) and thyme (Thymus vulgaris) to diet of laying hens and evaluating productive performance and egg quality characteristics. Am J Anim Vet Sci. 5(2): 151.

Gholijani N. and Z. Amirghofran (2016). Effects of thymol and carvacrol on $\mathrm{T}$-helper cell subset cytokines and their main transcription factors in ovalbuminimmunized mice. J Immunotoxicol. 13(5): 729737.

Gross W.B. and H.S. Siegel (1983). Evaluation of the heterophil/lymphocyte ratio as a measure of stress in chickens. Avian Dis. 27: 972-979.

Gumus R., N. Ercan and H. Imik (2017). The Effect of Thyme Essential Oil (Thymus Vulgaris) Added to Quail Diets on Performance, Some Blood Parameters, and the Antioxidative Metabolism of the Serum and Liver Tissues. Braz J Poult Sci. 19 (2): 297-304.

Haag W. (1985). On the methodology and practical meaning of vitamin $\mathrm{C}$ determination in cattle past and present. $\mathrm{PhD}$ Dissertation. Justus Liebig Universitaet, Giessen (In German).

Harikrishnan S. and R. Mohan (2018). Dietary Factors Improving Egg Shell Quality in Layer Chicken: A Review. Int J Pure Appl Biosci. 6 (5): 480-487.

Hashemipour H., H. Kermanshahi, A. Golian and T. Veldkamp (2013). Effect ofthymol and carvacrol feed supplementation on performance, antioxidant enzyme activities, fatty acid composition, digestive enzyme activities, and immune response in broiler chickens. Poultry Sci. 92: 2059-2069.

Hassan F.A.M. and A. Awad (2017). Impact of thyme powder (Thymus vulgaris L.) supplementation on gene expression profiles of cytokines and economic efficiency of broiler diets. Environ Sci Pollut Res Int. 24(5): 15816-15826.

Helander I.M., H.L. Alakomi, K. Latva-Kala, T. MattilaSandholm , I. Pol, E.J. Smid, L.G.M. Gorris and Wright A.V. (1998). Characterization of the action of selected essential oil components on 
gram-negative bacteria. J Agric Food Chem. 46: 3590-3595.

Jones G. (2001). High performing livestock and consumer protection are not contradictoryimpact of a phytogenic additive. Feed Mag. 12: 468-472.

Kaya A., H. Kaya, M. Macit, N. Esenbuga, M.A. Yoruk and Karaoglu M. (2013). Effects of Dietary Inclusion of Plant Extract Mixture and Copperinto Layer Diets on Egg Yield and Quality, Yolk Cholesterol and Fatty Acid Composition. Kafkas Univ Vet Fak Derg. 19 (4): 673-679.

Kirchgessner M. (1997). Animal RNA, 10th, Reworked Edition, Guide to Study, Advice and Practice. Publisher Union Agrar, ISBN 3-7690-0549-X, page. 140 (In German).

Kovacs M., T. Tuboly, M. Mézes, K. Balogh, Z. Gerencsér, Z. Matics, A.D. Bosco, Z. Szendrö, G. Tornyos, D. Hafner, G. Milisits, E. BaloghZándoki and A.D. Zotte (2016). Effect of dietary supplementation of spirulina arthrospira platensis) and thyme (Thymus vulgaris) on serum biochemistry, immune response and antioxidant status of rabbits. Ann Anim Sci. 19(1): 181-195.

Luckheeram R.V., R. Zhou, A.D. Verma and B. Xia (2012). CD4+ T-cells: Differentiation and functions. Clin Dev Immunol. 12: 1-12.

Mansoub N.H. (2011). Assessment on effect of Thyme on Egg Quality and Blood parameters of Laying Hens. Ann Biol Res. 4: 417-422.

Marri V. and H. Richner (2015). Immune response, oxidative stress and dietary antioxidants in great tit nestlings. Comp Biochem Physiol. 179: 192196.

Maxwell M. H. (1993). Avian blood leucocyte reponse to stress. Worlds Poult Sci J. 49(1): 34-43.
Moe R.O., D. Guémené, M. Bakken, H.J. Larsen, S. Shini, S. Lervik, E. Skjerve, V. Michel and R. Tauson (2010). Effects of housing conditions during the rearing and laying period on adrenal reactivity, immune response and heterophil to lymphocyte $(\mathrm{H} / \mathrm{L})$ ratios in laying hens. Animal. 4(10): 17091715.

Stringfellow K., D. Caldwel, J. Lee, M. Mohnl, R. Beltran, G. Schatzmayr, S. Fitz-Coy, C. Broussard, M. Farnell (2011). Evulation of probiotic administration on the immune response of coccidiosis-vaccinated broilers. Poultry Sci. 90(8): 1652-1658.

Sun Y., L.W. Oberley and Y. Li (1988). A simple method for clinical assay of superoxide dismutase. Clin Chem. 34(3): 497-500.

Swindle E.J. and D.D. Metcalfe (2007). The role of reactive oxygen species and nitric oxide in mast cell-dependent inflammatory processes. Immunol Rev. 217: 186-205.

Wigley, P. And P. Kaiser (2003). Avian Cytokines in Health and Disease. Br Poult Sci. 5(1): 1-14.

Yasmineh W.G., T.P. Kaur, B.R. Blazar and A. Theologides (1995). Serum catalase as marker of graft-vs-host disease in allogeneic bone marrow transplant recipients:pilot study. Clin Chem. 41(11): 1574-1580.

Yoshoiko, T., K. Kawada and T. Shimada (1979). Lipid peroxidation in maternal and cord blood and protective mechanism against actived-oxygen toxicity in the blood. Am J Obstet Gynecol. 135: 372-376.

Zeweil, H.S., S.G. Genedy and M. Bassiouni (2006). Effect of probiotic and medicinal plant supplements on the production and egg quality of laying Japanese quail hens. 12th Eur Poultry Conf. 3-8.

Zhang, J. and J. An ( 2007). Cytokines, inflammation and pain. Int Anesthesiol Clin. 45(2): 27-37. 